\title{
Effect of COVID-19 lockdown on reproductive activity in Rivers state
}

\author{
Barinua K. Gbaranor ${ }^{1 *}$, Humphrey N. Agara $^{2}$, Onisojime M. Alasia ${ }^{3}$, William A. Mube ${ }^{4}$, \\ Iboroma Dumoateli ${ }^{5}$, Blessing Z. Ovili-Odili ${ }^{6}$, Sofiri S. Peterside ${ }^{7}$, Vivian I. Ile ${ }^{8}$
}

\begin{abstract}
${ }^{1}$ Department of Human Physiology, College of Medical Sciences, Rivers State University, Port Harcourt, Nigeria ${ }^{2}$ Department of Medical Biochemistry, College of Medical Sciences, Rivers State University, Port Harcourt, Nigeria ${ }^{3}$ Department of Pharmacology, College of Medical Sciences, Niger Delta University, Bayelsa State, Nigeria ${ }^{4}$ Department of Obstetrics and Gynaecology, University of Port Harcourt Teaching Hospital, Port Harcourt, Nigeria ${ }^{5}$ Department of Human Anatomy, College of Medical Sciences, Rivers State University, Port Harcourt, Nigeria ${ }^{6}$ Department of Human Physiology, College of Health Sciences, University of Port Harcourt, Port Harcourt, Nigeria ${ }^{7}$ Department of Community Medicine, Rivers State Ministry of Health, Port Harcourt, Nigeria

${ }^{8}$ Department of Family Medicine, Rivers State University Teaching Hospital, Port Harcourt, Nigeria
\end{abstract}

Received: 13 May 2021

Revised: 01 July 2021

Accepted: 02 July 2021

\author{
*Correspondence: \\ Dr. Barinua K. Gbaranor, \\ E-mail: barinua.gbaranor@ust.edu.ng
}

Copyright: ( $)$ the author(s), publisher and licensee Medip Academy. This is an open-access article distributed under the terms of the Creative Commons Attribution Non-Commercial License, which permits unrestricted non-commercial use, distribution, and reproduction in any medium, provided the original work is properly cited.

\begin{abstract}
Background: Reproductive activity is an important biological process that always take place between married and unmarried couples across the globe. The study was carried out to evaluate the effect of COVID-19 on reproductive activity during and post-lockdown in Rivers state. The aim of the study was to evaluate the effect of COVID-19 on reproductive activity during and post-lockdown in Rivers state.

Methods: A well-structured questionnaire containing demographics and effect of COVID-19 on reproductive activity were administered to participants. Each participant had one questionnaire to fill appropriately and independently after instructions were given to them by the researchers.

Results: The study revealed that $57.58 \%$ (57/99) of the participants were between the ages $16-20,58.82 \%(60 / 102)$ were single and $99.03 \%$ (102/103) of the participants (women) have unprotected sexual intercourse during COVID-19 lockdown. $99.03 \%(102 / 103)$ the participants engaged in unprotected sex because the pharmacist's stores were closed. The study also shows that $43.69 \%$ (103) have the urge for sex due to inactivity and $76.60 \%$ (102) of the participants got pregnant and $96.25 \%(77 / 80)$ of the pregnancy were not planned. 51.29\% (41/80) of the participants aborted the pregnancy and $92.68 \%$ (38/41) of the women who got pregnant did not attend antenatal clinic.

Conclusions: A total number of 103 respondents participated in the research. $76.6 \%$ of the population got pregnant during the lockdown for different reasons and most of the participants were singles and did not plan for the pregnancy.
\end{abstract}

Keywords: Effect, COVID-19, Reproductive activity, Lockdown

\section{INTRODUCTION}

Reproduction is an important aspect of African culture with the aim to maintain continuity in the family circle. ${ }^{2}$ Reproductive activity is an act carried out by men and women who have attained pubertal age to obtain pleasure when pregnancy is not plan or desire and this may or may not result to pregnancy or sexually transmitted disease in the absent of a protective device. So many people carried out reproductive activity extramaritally without the use of protective device.

Coronavirus is a genus of the coronaviridae family, that may cause infection in animals or humans. ${ }^{10,11}$ Severe 
acute respiratory syndrome coronavirus 2 (SARS-CoV-2) is one of the six types of viruses from the coronaviridae's family responsible for the Coronavirus disease 2019, and is commonly known as COVID-19. ${ }^{1}$ COVID-19 as the name implies, was discovered in the last quarter of 2019 in the city of China called Wuhan.

The main form of transmission of the virus is from person to person through droplets derived from sneezing and coughing. ${ }^{8}$ The gold standard use for diagnosis is the realtime reverse transcription polymerase chain reaction (RTPCR) of samples collected by nasopharyngeal and oropharyngeal swab. ${ }^{5}$ However, the virus has been isolated in saliva, conjunctiva, urine, and faeces from infected patients. ${ }^{4,7,15}$ Symptoms of COVID-19 include: difficulty in breathing, cough, chest pain, sore throat, fever, anosmia, and other respiratory symptoms.

Elderly people and those with co-morbidities such as diabetes, heart problems, and hypertension are more susceptible to develop the disease. ${ }^{13}$ Some preventive measures are physical distancing, wearing face mask, regular washing of hands under running water with soap, use of hand sanitizer and restriction of movement. COVID-19 was announced as pandemic by the WHO. ${ }^{13}$ To reduce transmission, travel restrictions have been announced and enforced around the world, and most cities have been quarantined. ${ }^{9}$

\section{METHODS}

\section{Study type}

This was a cross-sectional study (descriptive study) involving 103 females.

\section{Study place}

The study place was households in Rivers state, SouthSouth, Nigeria. The study lasted for a period of six weeks, from February 2021 to March 2021.

\section{Selection criteria}

Inclusion criteria were those that were between 16 years to 40 years and exclusion criteria were those less than 16 years of age and above 40 years of age.

A well-structured questionnaire containing demographics and effect of COVID-19 on reproductive activity were administered to participants. Each participant had one questionnaire to fill appropriately and independently after instructions were given to them by the researchers. The age of the participants was between 16 and 40 years.

\section{Ethical approval}

There was no ethical approval because the study was conducted in an open area during the lockdown and every government office was under luck and key.

\section{Statistical analysis}

Data was done using Microsoft excel. $\mathrm{P}$ value 0.05 was considered significant for data.

\section{RESULTS}

The participants ages were 16-20 years, $57.58 \%$ (57/99); 21-25 years, $28.28 \%$ (28/99); 26-30 years, $8.09 \%$, (8/99) (Table 1) and 31-35 years, 6.06\% (6/99). 58.82\% (60/102) were singles, $31.37 \%$ (32/102) married, $4.90 \%(5 / 102)$ divorced, $3.92 \%$ (4/102) cohabiting and $0.98 \%(1 / 102)$ widow (Table 2) respectively. Also, $46.08 \%$ (47/102) of the participants were students, 35.29\% (36/102) were traders, $16.67 \%(17 / 102)$ were civil servants and $1.98 \%$ $(2 / 102)$ were farmers (Table 3$)$.

$49.02 \%(50 / 102)$ of the respondents were in secondary school, $50 \%(51 / 102)$ in tertiary institution and $0.98 \%$ $(1 / 102)$ in primary school (Table 4$) .99 .03 \%$ (102/103) of the respondents engaged in unprotected sex during the lockdown and $0.97 \%$ (1/103) do not and 99.03\% (102/103) engaged in unprotected sex due to closure of pharmacist's store (Table 5). $43.69 \%(45 / 103)$ of the respondents engaged in sexual activity due to inactivity, $22.33 \%$ (23/103) due to idleness, $22.33 \%(23 / 103)$ due to lack of finance and $11.65 \%(12 / 103)$ due to lockdown at home (Figure 1). Among the participants, 76.60\% (80/102) were pregnant and $23.40 \%(22 / 102)$ were not pregnant (Table 6).

The study revealed that $96.25 \%$ (77/80) of the respondents did not plan for the pregnancy while $3.75 \%$ (3/80) actually planned the pregnancy (Table 7). 51.25\% (41/80) of the respondents aborted the pregnancy and 48.75\% (39/80) maintained the pregnancy (Figure 2). 12\% (6/50) of the participants had complications from abortion and $88 \%$ (44/50) of the participants did not (Table 8). 92.68\% (38/41) of the participants did not attend antenatal while $7.32 \%(3 / 41)$ of the participants attended antennal (Table 9).

Table 1: Demography.

\begin{tabular}{|lll|}
\hline Age (years) & $\mathbf{N}$ & Percentage (\%) \\
\hline $\mathbf{1 6 - 2 0}$ & 57 & 57.58 \\
\hline $\mathbf{2 1 - 2 5}$ & 28 & 28.28 \\
\hline $\mathbf{2 6 - 3 0}$ & 8 & 8.09 \\
\hline $\mathbf{3 1 - 3 5}$ & 6 & 6.06 \\
\hline $\mathbf{3 6 - 4 0}$ & 0 & 0 \\
\hline
\end{tabular}

Table 2: Marital status.

\begin{tabular}{|lll|}
\hline Marital status & $\mathbf{N}$ & Percentage (\%) \\
\hline Single & 60 & 58.82 \\
\hline Married & 32 & 31.37 \\
\hline Divorced & 5 & 4.90 \\
\hline Cohabiting & 4 & 3.92 \\
\hline Widow & 1 & 0.98 \\
\hline
\end{tabular}


Table 3: Occupation.

\begin{tabular}{|lll|}
\hline Occupation & N & Percentage (\%) \\
\hline Student & 47 & 46.08 \\
\hline Farming & 2 & 1.96 \\
\hline Trading & 36 & 35.29 \\
\hline Civil servant & 17 & 16.67 \\
\hline
\end{tabular}

Table 4: Educational status.

\begin{tabular}{|lll|}
\hline Educational status & $\mathbf{N}$ & Percentage (\%) \\
\hline Formal & 0 & 0 \\
\hline Primary & 1 & 0.98 \\
\hline Secondary & 50 & 49.02 \\
\hline Tertiary & 51 & 50 \\
\hline
\end{tabular}

Table 5: Respondents who had unprotected sex.

\begin{tabular}{|lll|}
\hline Responses & N & Percentage (\%) \\
\hline Yes & 102 & 99.03 \\
\hline No & 1 & 0.97 \\
\hline
\end{tabular}

Table 6: Respondents who were pregnant during the lockdown.

\begin{tabular}{|lll|}
\hline Responses & N & Percentage (\%) \\
\hline Yes & 80 & 76.60 \\
\hline No & 22 & 23.40 \\
\hline
\end{tabular}

Table 7: Respondents who did not plan for pregnancy.

\begin{tabular}{|lll|}
\hline Responses & N & Percentage (\%) \\
\hline Yes & 3 & 3.75 \\
\hline No & 77 & 96.25 \\
\hline
\end{tabular}

Table 8: Respondents who had complications from aborted pregnancy.

\begin{tabular}{|lll|}
\hline Responses & N & Percentage (\%) \\
\hline Yes & 6 & 12 \\
\hline No & 44 & 88 \\
\hline
\end{tabular}

Table 9: Respondents who attended antenatal during pregnancy.

\begin{tabular}{|lll|}
\hline Responses & N & Percentage (\%) \\
\hline Yes & 3 & 7.32 \\
\hline No & 38 & 92.68 \\
\hline
\end{tabular}

Table 10: Representation of the reproductive activity during lockdown based on age groups.

\begin{tabular}{|c|c|c|c|c|c|}
\hline $\begin{array}{l}\text { Age groups } \\
\text { (years) }\end{array}$ & $\begin{array}{l}\text { Total no. of } \\
\text { respondents in } \\
\text { each class group }\end{array}$ & $\begin{array}{l}\text { No. of respondents } \\
\text { who got pregnant in } \\
\text { lockdown }(\%)\end{array}$ & $\begin{array}{l}\text { P value } \\
(<0.05)\end{array}$ & $\begin{array}{l}\text { No. of respondents who } \\
\text { did not get pregnant in } \\
\text { lockdown }(\%)\end{array}$ & $\begin{array}{l}\text { P value } \\
(<0.05)\end{array}$ \\
\hline $16-20$ & 24 & $12(15)$ & \multirow{6}{*}{$<0.009$} & $12(54.5)$ & \multirow{6}{*}{$<0.003$} \\
\hline 21-25 & 25 & $20(25)$ & & $5(22.7)$ & \\
\hline $26-30$ & 37 & $34(42.5)$ & & $3(13.6)$ & \\
\hline 31-35 & 16 & $14(17.5)$ & & $2(9.2)$ & \\
\hline \multirow[t]{2}{*}{$36-40$} & 0 & 0 & & 0 & \\
\hline & & Mean $=26.1$ & & Mean $=21.8$ & \\
\hline
\end{tabular}


Table 11: Reasons why pregnancy was not planned.

\begin{tabular}{|lll|}
\hline Reasons & N & Percentage (\%) \\
\hline Hardship & 14 & 18.18 \\
\hline Restriction & 18 & 23.38 \\
\hline No access to health facility & 33 & 42.86 \\
\hline Shortage of food & 12 & 15.58 \\
\hline
\end{tabular}

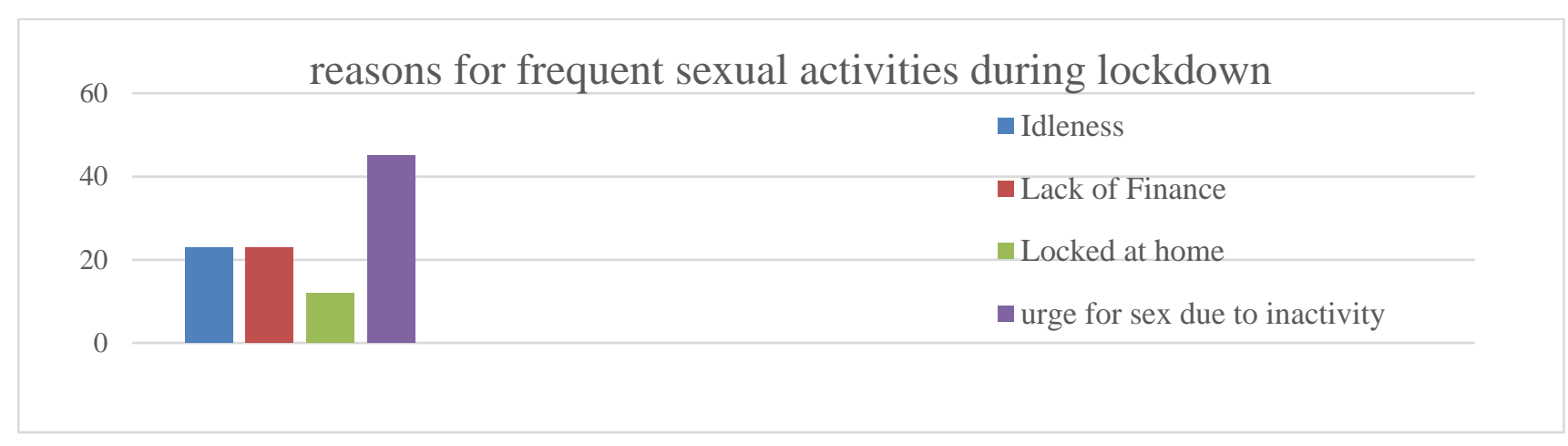

Figure 1: Reasons for frequent sexual during lockdown.

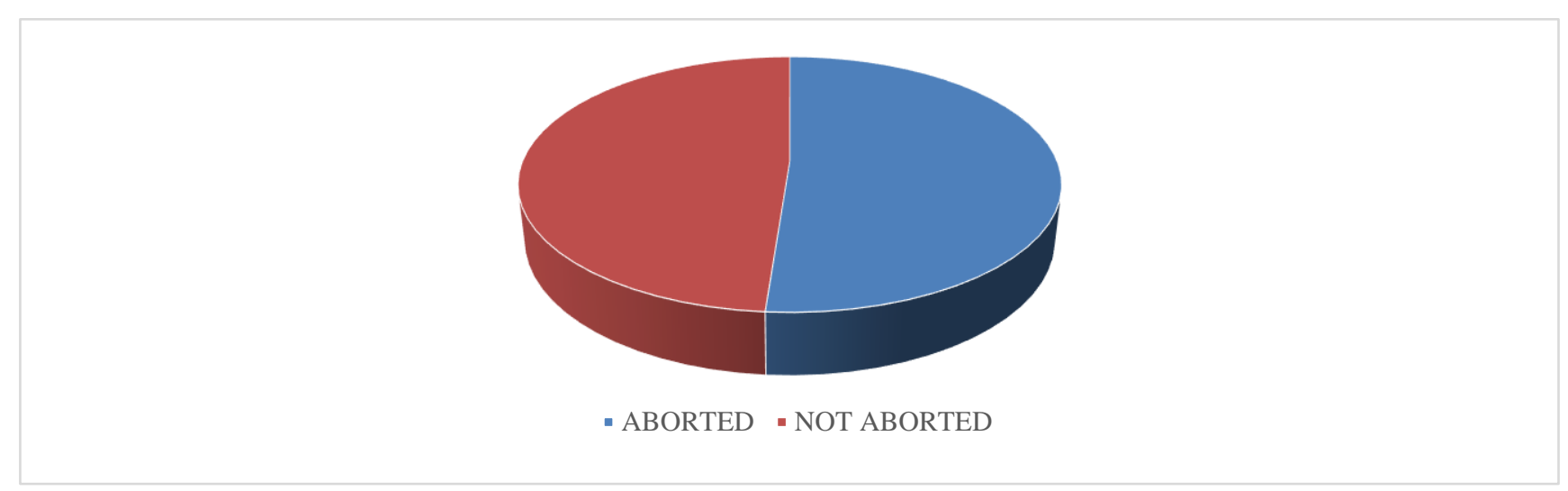

Figure 2: Representations of aborted pregnancies during the lockdown.

\section{DISCUSSION}

Reproductive activity is an act carried out by men and women who have attained pubertal age to obtain pleasure when pregnancy is not plan or desire and this may or may not result to pregnancy or sexually transmitted disease in the absent of a protective device. Unprotected sexual intercourse is sex that occur between a man and a woman who have attained pubertal age without the use of any one of the family planning methods. Sex is pleasurable and must be control to avoid embarrassment mostly among unmarried couples. If sex is not control it could result to unwanted pregnancy and other sexually transmitted infections and this can also lead to school dropout, frustration, isolation and depression. During COVID-19 lockdown and post COVID-19 lockdown, sexual activities were on the increase due to factors such as loneliness, lack of finance, hunger and overcrowding around the neighbourhood and because these factors were present, the participants (women) were prone to have sex in order to take care of themselves and also keep themselves busy. COVID-19 pandemic fractured several sectors such as agriculture, economy, pollical, education social events across the globe. During the pandemic, almost all the sectors were shut down and people were home without participating in any activity.

Effects of COVID-19 on reproductive activity appears to be commoner among students who were idle and restricted. The study revealed that $46.08 \%$ of the participants were students, $35.29 \%$ were traders, $16.67 \%$ were civil servants and $1.96 \%$ were farmers (Table 3 ). Among the participants, $99.03 \%$ of them had unprotected sexual intercourse during the lockdown and this is an unsafe pattern of sex among unmarried couples and married couples who has not plan or desired to have children (Table 5). $99.03 \%$ of the participants who engaged in unprotected sex did it because there was no place to purchase family planning devices such as condoms, oral contraceptives and others. The pharmacist's 
store was closed preventing the participants from getting access to the devices. This study is similar to studies by ${ }^{1}{ }^{6}$ which revealed that there were declined in the utilization of family planning, antenatal care and institutional deliveries during the Ebola outbreak in 2014-2015. Among the participants, several reasons such as idleness, lack of finance, locked at home and urge to sex due to inactivity were responsible for frequent sexual activities during the lockdown (Fig 1). However, urge due to inactivity tend to be the most reason for the frequent unprotected sex during the outbreak and this is because people were home doing nothing and this could result to unexpected visit from friends.

However, $76.60 \%$ of the participants got pregnant for different reasons and $23.40 \%$ did not get pregnant during the COVID-19 lockdown and this increased in percentage of those that got pregnant could be due to lack of protective devices as result of restriction of movement, closure of medical stores or scarcity of those protective devices. During the period, pharmacist's stores were closed, no access to medical supplies resulting to most of the participants engaging in unprotected sex leading to pregnancy. The mean of those who got pregnant is 26.1 while that of those who did not get pregnant is 21.8 (Table 10). $96.25 \%$ of the participants actually did not plan for the pregnancy due to hardship (18.18\%), restriction (23.38\%), no access to health facility $(42.86 \%)$ and shortage of food $(15.58 \%)$ (Table 11$)$. The study shows that $51.25 \%$ of the participants who got pregnant aborted the pregnancy and $48.75 \%$ did not abort the pregnancy (Figure 2). Meanwhile, $92.68 \%$ of the participants who did not abort the pregnancy, did not attend antenatal clinic (Table 9). This may due to restriction of movement during the lockdown. Access to healthcare facility were hindered during the COVID-19 lockdown and this affected many pregnant women. During this period expectant mothers were not able to access healthcare facility due to restrictions of movement, transportation and healthcare providers were also restricted due to lack of transportation vehicles that normally convey them to their various centres. This study agreed with study by WHO, 2018, who revealed that persons with health problems unrelated to the epidemic find it harder to get access to health care services.

Number of participants who got pregnant during the lockdown were between the ages: 16-20 years and were $15 \%(12)$, and the least among the age class and probably at that age, they were still tender and $42.5 \%$ (34) of the respondents who got pregnant were between the age 26-30 years and this was the highest (Table 1). This could be that the respondents were actually looking for an avenue to get someone that they may settle with and plan their future. However, their plan may not be perfect as expected due to the effect of the COVID-19 pandemic. $17.5 \%$ (14) of the respondents in age class between 31-35 years got pregnant and this was less than age class between $26-30$ years. This low percentage of this group may due to the fact that, they were matured enough to handle situations when it comes to sexual activity and to avoid embarrassment. In the age class between 21-25 years $25 \%$ (20) of the respondents got pregnant during the lockdown (Table 10).

Again, 58.82\% of the participants were singles (Table 2), probably because most of them were students and this could be the reason while most of the participants who got pregnant did not plan for the pregnancy and they went further to aborts the pregnancy. COVID-19 pandemic that brought about lockdown have caused havoc to our future workforce because most the participants were students who engaged in unprotected sex and this is responsible to the unwanted pregnancy they got. Most of them may dropout of school due to social stigmatization, lack of family support, finance, psychological factors like isolation and depression.

\section{Limitations}

The following were limitations of the study, they were restriction of movement, fear of contacting the virus, and lack of fund.

\section{CONCLUSION}

A total number of 103 respondents participated in the research. $76.6 \%$ of the population got pregnant during the lockdown for different reasons and most of the participants were singles and did not plan for the pregnancy which resulted to abortion by the participants and this may cause most of the participants to drop-out of school due to psychological factors, lack of finance and lack of family support.

\section{ACKNOWLEDGMENTS}

We acknowledge Nazor Barinua Gbaranor, Nuazor V. Barinua Gbaranor, Kedumle S. Barinua Gbaranor and Manasseh for their support, understanding encouragement during this period of research.

\section{Funding: No funding sources \\ Conflict of interest: None declared \\ Ethical approval: Not required}

\section{REFERENCES}

1. CDC. COVID Tracker, 2021. Available at: https://www.cdc.gov/coronavirus/2019ncov/index.ht ml. Accessed on 2 May 2021.

2. Godam ET, Olaniyan OT, Wofuru CD, Orupabo CD, Ordu KS, Gbaranor BK, et al. Xylopia aethiopica ethanol seed extract suppresses Cadmium chlorideinduced ovary and gonadotropins toxicity in adult female Wistar rats. JBRA Assist Reprod. 2021;25(2):252-6.

3. Camara BS, Delamou A, Diro E, Beavogui AH, Ayadi AM, Sidibe S, et al. Effect of the 2014/2015 Ebola outbreak on reproductive health services in a rural district of Guinea: an ecological study. Trans R Soc Trop Med Hyg. 2017;111(1):22-9. 
4. Chen L, Zhao J, Peng J, Li X, Deng X, Geng Z, et al. Detection of SARS-CoV-2 in saliva and characterization of oral symptoms in COVID-19 patients. Cell Prolif. 2020;53(12):12923.

5. Corman VM, Landt O, Kaiser M, Molenkamp R, Meijer A, Chu DK, et al. Detection of 2019 novel coronavirus (2019-nCoV) by real-time RT-PCR. Euro Surveill. 2020;25(3):2000045.

6. Delamou A, Ayadi AME, Sidibe S, Delvaux T, Camara BS, Sandouno SD, et al. Effect of Ebola virus disease on maternal and child health services in Guinea: a retrospective observational cohort study. Lancet Glob Health. 2017;5(4):448-57.

7. Guan WJ, Ni ZY, Hu Y, Liang WH, Ou CQ, He JX, et al. Clinical Characteristics of Coronavirus Disease 2019 in China. N Engl J Med. 2020;382(18):1708-20.

8. Guo YR, Cao QD, Hong ZS, Tan YY, Chen SD, Jin $\mathrm{HJ}$, et al. The origin, transmission and clinical therapies on coronavirus disease 2019 (COVID-19) outbreak - an update on the status. Mil Med Res. 2020;7:11.

9. Papadimos TJ, Marcolini EG, Hadian M, Hardart GE, Ward N, Levy MM, et al. Ethics of outbreaks position statement. Part 2: family-centered care. Crit Care Med. 2018;46(11):1856-60.
10. Hoek L, Pyrc K, Jebbink MF, Vermeulen OW, Berkhout RJ, Wolthers KC, et al. Identification of a new human coronavirus. Nat Med. 2004;10(4):36873.

11. WHO. Novel coronavirus (2019-nCoV) situation reports, 2021. Available at: https://www.who.int/ emergencies/diseases/novelcoronavirus-2019/ situation-reports. Accessed on 2 May 2021.

12. WHO. Managing epidemics: key facts about major deadly diseases, 2021. https://www.who.int/ emergencies/diseases/managingepidemics/en/. Accessed on 1 May 2021.

13. WHO. Q\&A on coronaviruses COVID (2000-19), 2021. Available at: https://www.who. int/newsroom/q-a-detail/q-a-coronaviruses. Accessed on 2 May 2021.

14. Xia J, Tong J, Liu M, Shen Y, Guo D. Evaluation of coronavirus in tears and conjunctival secretions of patients with SARS-CoV-2 infection. J Med Virol. 2020;92(6):589-94.

Cite this article as: Gbaranor BK, Agara HN, Alasia OM, Mube WA, Dumoateli, Odili BZO, et al. Effect of COVID-19 lockdown on reproductive activity in Rivers state. Int J Reprod Contracept Obstet Gynecol 2021;10:2969-74. 